\title{
降雨を伴う風速の再現期待值 \\ EXTREME WIND SPEEDS FOR VARIOUS RETURN PERIODS DURING RAINFALL
}

\author{
村 上周三*, 茅野紀子**, 佐藤 秀雄 ${ }^{* * *}$ \\ Shuzo MURAKAMI, Noriko CHINO and Hideo SATO
}

\begin{abstract}
Extreme wind speeds for various return periods during rainfall at 49 meteorological stations in Japan were estimated using the statistical method for extremes. The 10 minutes average wind speeds and hourly precipitations for 13 years were used for analysis. These wind speeds were classified into seven categories according to the amount of hourly precipitation. Annual maximum wind speeds in each precipitation class were then extracted from these data. Multiple regression analysis, which assumed that annual maximum wind speed during rainfall was a linear function of a reduced variate and of hourly precipitation, was used to fit the extreme type-I distribution.
\end{abstract}

Keywords : water proof, wall, roof, wind velocity, extreme value 防水，壁，屋根，風速，極值

\section{1. まえがき}

建物の外壁面あるいは屋根面の水密設計において，漏 水危険率は，降水量およびその時同時に作用する風圧力 の発生確率により算定される。このため, 降雨時の風速 とその発生確率に関する検討が重要である。これに関連 した既往の研究としては, 全国の気象官署における風速 の再現期待値（降雨時に限らない場合）が, 数件報告さ れている1 海。また全国の 20 地点について，風速と降 水量の 10 年間の観測資料から，降雨時の風速の超過頻 度が整理されている4)。しかし，水密設計上必要と考え られる降雨時の風速の長期間の発生確率を推定した例は 見られない。このようなことから筆者らは, 既報ら〜7に おいて, 風と雨が同時に生じる場合の風速の再現期待値 に関し推定方法の検討を行い,全国の代表的な 6 都市(札 䖧, 仙台, 東京, 名古屋, 大阪, 福岡) における解析結 果を示した。その後さらにデータの充実を目的として，

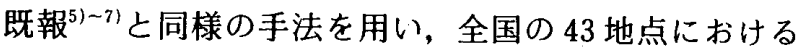
降雨時の風速の再現期待値を推定したので, 上述の 6 都 市の結果と併せ，ここに報告する。

\section{2. 解析概要}

2.1 降水量および年最大風速の観測資料

図-1に，解析の対象とした 49 の気象官署の位置を

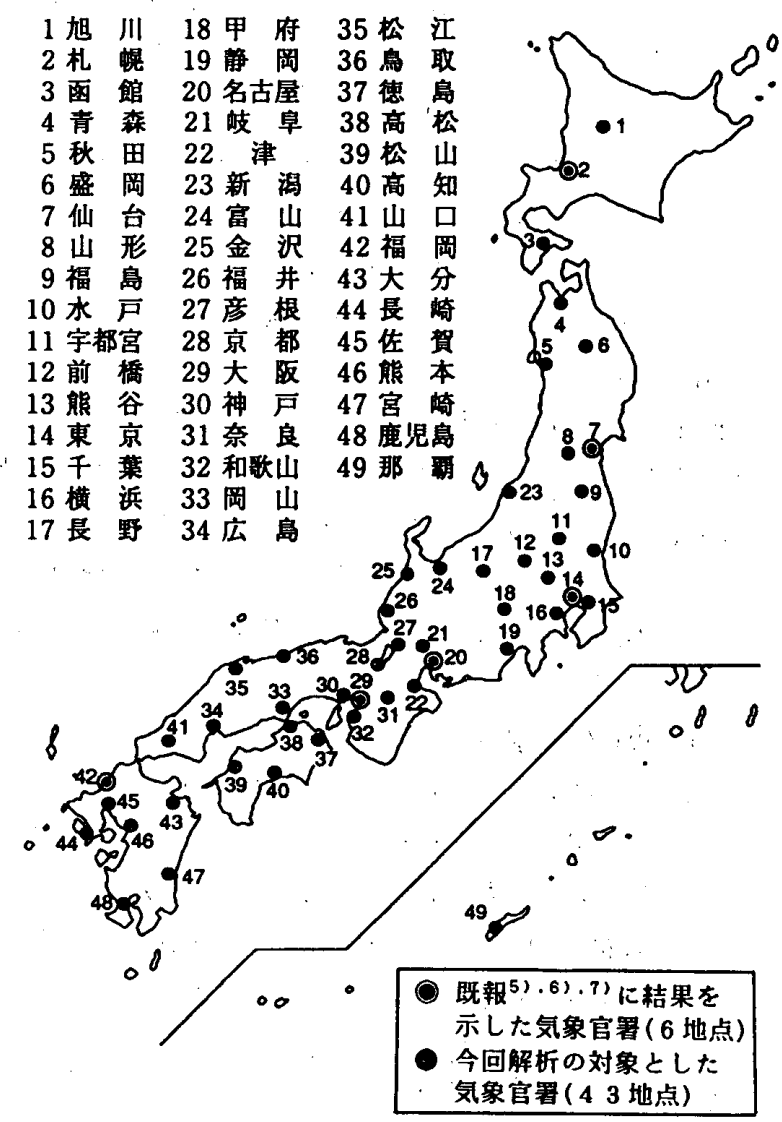

図一1 解析対象地点
* 東京大学生産技術研究所 教授・工博

***竹中工務店技術研究所 研究員

***. 竹中工務店技術研究所 主任研究員 ·工修
Prof., Institute of Industrial Science, Univ. of Tokyo, Dr. Eng. Research Engineer, Technical Research Laboratory, Takenaka Corp. Senior Research Engineer, Technical Research Laboratory, Takenaka Corp., M. Eng. 
示す。観測資料としては，今回解析の対象とした 43 地 点については，1976 1988 年の 13 年間（ただし鳥取の み, $1977 \sim 1988$ 年の 12 年間) の毎時の 1 時間降水量お よび 10 分間平均風速を用い，1 時間降水量の階級別に 年最大風速を抽出した。1 時間降水量の階級は, $5 \mathrm{~mm}$ 以上, $7 \mathrm{~mm}$ 以上, $11 \mathrm{~mm}$ 以上, $21 \mathrm{~mm}$ 以上, $31 \mathrm{~mm}$ 以 上， $41 \mathrm{~mm}$ 以上， $51 \mathrm{~mm}$ 以上の 7 段階とした。また既 報 ${ }^{517)}$ に示した札幌, 仙台, 東京, 名古屋, 大阪, 福岡 の 6 地点については, 統計期間は 1961 1980 前の 20 年 間である(詳細は，既報5) 7)を参照)。

なお表一1に各地点の風速観測高さを示すが, 上述の 統計期間中に観測高さが変更された地点がある。このた め，年最大風速を（1）式を用いて地上 $10 \mathrm{~m}$ における 風速値に換算し, 解析に用いた。

$$
V_{10}=V_{M} \cdot\left(10 / h_{M}\right)^{1 / 7}
$$

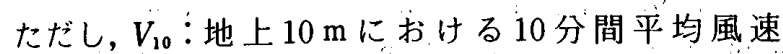
$(\mathrm{m} / \mathrm{s})$

$V_{M}:$ 気象官署の風速観測高さ $\left(h_{M}\right)$ における 10 分間平均風速 $(\mathrm{m} / \mathrm{s})$

$h_{M}:$ 風速観測高さ $(\mathrm{m})$

表一2に，解析に用いた観測値の例として，旭川にお ける 13 年間の降雨時の年最大風速を大きさの順に並べ 変えた順位表を示す。なお同表に示す非超過確率 $F_{i}$ は, (2).式に示すへイズンプロットにより求めた。

$$
F_{i}=1-(2 i-1) / 2 N
$$

ただし, $N$ : 標本数

\section{$i:$ 年最大風速を大きい方から数えた順位 \\ $F_{i}:$ 大きさ $i$ 番目の年最大風速の非超過確率}

\section{2 解析方法}

風速 $V_{T}$ 以上の風が平均的にみて $T$ 年に一度の割合 で起こると期待されるとき，この $T$ 年を風速 $V_{T}$ に対 する再胃期間といい， $V_{T}$ を $T$ 年再現期待値という。年 最大風速を $V$, その確率分布関数を $F(V)$ とすれば, ある年の年最大風速が $V_{\boldsymbol{T}}$ を超える確率（超過確率） は,

$$
\operatorname{Prob}\left(V>V_{T}\right)=1-F\left(V_{T}\right)
$$

で表され，超過確率と再現期間 $T$ の関係は，

$$
1-F\left(V_{\tau}\right)=1 / T
$$

で表される。すなわち, 確率分布関数 $F(V)$ が確定すれ ば，（4）式により風速の $T$ 年再現期待値が得られる。

年最大風速の確率分布関数としでは, 一般には Fisher-Tippett $\Phi$ I 型分布 (Gumbel 分布, (5), (6) 式）が多く用いられている(1)

$$
\begin{aligned}
& F(V)=\exp \left(-e^{-y}\right) \\
& y=a(V-b) \cdots \cdots \cdots
\end{aligned}
$$

ただし， $V^{\prime}:$ 年最大風速 $(\mathrm{m} / \mathrm{s})$

\begin{tabular}{|c|c|c|c|c|c|}
\hline 点 & 高さ (m) & 地 点 & 高さ (m) & 地 点 & 高さ (m) \\
\hline$\Pi$ & 14.7 & 熊 谷 & 16.9 & 德 島 & 17.4 \\
\hline 館 & 15. 9 & 横 浜 & 20.2 & 高 松 & 16. 5 \\
\hline 青 & 17. 1 & 長 & 18. 3 & 松 山 & 20.5 \\
\hline 秋 & 20.5 & 府 & 17. 6 & 高 知 & 14. 6 \\
\hline 岡 & 15. 9 & 静 & 16. 2 & 山 & 15. 3 \\
\hline 台 & 15. 8 & 名古屋 & 17. 5 & 大 分 & 19. 8 \\
\hline 山 & 14. 8 & 金 沢 & 13. 4 & 長 & 18. 7 \\
\hline 福 島 & 26. 0 & 彦 根 & 17. 5 & 佐 & 25. 5 \\
\hline 戸 & 14. 1 & 京 & 16. 0 & 能 & 14. 8 \\
\hline 宇都宮 & 15.: 2 & 戸 & 27. 0 & 宫 崎 & 21.1 \\
\hline 前 檑 & 17. 3 & 奈 良 & 11. 2 & 鹿児島 & 22. 0 \\
\hline
\end{tabular}

$F(V)$ ：確率分布関数（非超過確率）

$y:$ 規準極值変量

\section{表一1 風速観測高さ}

\begin{tabular}{|c|c|c|c|c|c|}
\hline 地，点 & ，期 間 & $\begin{array}{r}\text { 高さ } \\
\text { (m) }\end{array}$ & 地. 点 & 期 & $\begin{array}{l}\text { 高さ } \\
\text { (m) }\end{array}$ \\
\hline \multirow[t]{2}{*}{ 札 幌 } & '61.1 ' 74.12 & 17.3 & \multirow[t]{2}{*}{ 大 吸 } & '61. 1 ' 68 : 7 & 18.6 \\
\hline & $75.1 \sim 80.12$ & 19.9 & & 68. $8-80.12$ & 53.0 \\
\hline \multirow[t]{4}{*}{ 千，葉 } & '76.1 ' 78.12 & 27.0 & \multirow[t]{2}{*}{ 和歌山 } & '76. 1 '77. 3 & 16.0 \\
\hline & $79.1 \sim 80.12$ & 28.8 & & '77. $4 \sim 98.12$ & 18.0 \\
\hline & $81.1 \mathcal{L}^{\prime} 81.3$ & 27.0 & \multirow[t]{2}{*}{ 网山 } & '76. 1 ' 82.9 & 12.7 \\
\hline & '81.4 ' 88.12 & 47.8 & & $\cdot 82.10 \sim \cdot 88.12$ & 43.0 \\
\hline \multirow[t]{3}{*}{ 東 京 } & '61.1 ' 64.12 & 26.9 & \multirow[t]{2}{*}{ 広 島 } & '76. $1 \sim ' 87.12$ & 19.3 \\
\hline & '65.1 ' 78.12 & 52.2 & & '88. 1 ' 88.12 & 94.9 \\
\hline & '79.1 ' 80.12 & 74.6 & \multirow[t]{2}{*}{ 鳥 取 } & '77. 1 '77.10 & 13.8 \\
\hline \multirow[t]{2}{*}{ 畦 阜 } & :76.1 ' 80.12 & 14.4 & & $' 77.11 \sim \cdot 88.12$ & 32.0 \\
\hline & '81.1 ' 88.12 & 22.8 & \multirow[t]{2}{*}{ 松 江 } & '76. 1 '79.10 & 15.7 \\
\hline \multirow[t]{2}{*}{ 津 } & '76.1 ' 87.8 & 15.4 & & '79.11 ' 88.12 & 26.7 \\
\hline & '87.9' 88.12 & 39.7 & \multirow[t]{2}{*}{ 楅 岡 } & $61.1 \sim 74.7$ & 19.0 \\
\hline \multirow[t]{2}{*}{ 新擝 } & '76.1 '81. 3 & 15.9 & & '74. 8- 80.12 & 24.3 \\
\hline & '81.4 ' 88.12 & 18.6 & \multirow{2}{*}{ 那 霸 } & '76. 1 ' 87.2 & 20.6 \\
\hline \multirow[t]{2}{*}{ 富山 } & $76.1 \sim 85.12$ & 14.0 & & '87. 3 ' 88.12 & 47.8 \\
\hline & '86.1 ' 88.12 & 20:0 & \multirow{4}{*}{$\begin{array}{cc}\ddots & \\
\vdots & \vdots \\
\vdots & \vdots\end{array}$} & & \\
\hline \multirow[t]{3}{*}{ 福井 } & $76.1 \sim 76.7$ & 14.4 & & & \\
\hline & '76.8 ' 77. 1 & 19.4 & & & \\
\hline & '77.2 ' 88.12 & 26.1 & & & \\
\hline
\end{tabular}

(a ) 統計期間中一定の地点

（ただし、1.0m以下の変更は無規した。）

（b）統計期間中に変更のあった地点 (ただし、1.0m以下の变更は無視した。)

表一2 年最大風速の順位表

(単位; m/s, 旭川, 1976 1988)

\begin{tabular}{|r|r|r|r|r|r|r|r|r|}
\hline 順位 & 非超過 & \multicolumn{5}{|c|}{1 時間降水量 $\mathrm{H}$ (m m以上) } \\
\cline { 3 - 8 } & 確率 Fi & 5 & \multicolumn{1}{|c|}{7} & \multicolumn{1}{c|}{11} & 21 & 31 & 41 & 51 \\
\hline 1 & 0.9615 & 12.3 & 12.3 & 12.3 & 2.8 & 1.9 & - & - \\
2 & 0.8846 & 6.6 & 6.6 & 4.7 & 1.9 & 0.9 & - & - \\
3 & 0.8077 & 6.6 & 5.7 & 3.8 & 1.9 & - & - & - \\
4 & 0.7308 & 5.7 & 5.7 & 3.8 & 1.9 & - & - & - \\
5 & 0.6538 & 5.7 & 4.7 & 2.8 & 0.9 & - & - & - \\
6 & 0.5769 & 5.7 & 4.7 & 2.8 & - & - & - & - \\
7 & 0.5000 & 5.7 & 4.7 & 2.8 & - & - & - & - \\
8 & 0.4231 & 5.7 & 4.7 & 2.8 & - & - & - & - \\
9 & 0.3462 & 4.7 & 4.7 & 1.9 & - & - & - & - \\
10 & 0.2692 & 4.7 & 3.8 & 1.9 & - & - & - & - \\
11 & 0.1923 & 4.7 & 3.8 & 1.9 & - & - & - & - \\
12 & 0.1154 & 4.7 & 3.8 & 0.9 & - & - & - & - \\
13 & 0.0385 & 3.8 & 2.8 & - & - & - & - & - \\
\hline
\end{tabular}

（注）表中の風速值は, 地上高さ $10 \mathrm{~m}$ 換算された年最大 風速を表す..また非超過確率Fiは，ヘイズンプロット $\mathrm{Fi}=1-(2 \mathrm{i}-1) / 2 \mathrm{~N}$ により求めた。 


$$
(y=-1 n(-1 n F(V)))
$$

$a, b$ : 定数

本報では, 降雨時に限うた場合の年最大風速の確率分 布関数に関しても，既報 ${ }^{5 \sim 7)}$ と同様，1 時間降水量の階 級ごとの年最大風速の分布はFisher-Tippett のI 型分 布に適合する（すなわち，降雨時の年最大風速 $(V)$ は規 準極值変量 $(y)$ に比例する，（6）式参照）と仮定した。 また降水量と年最大風速の関係に関しては, 本報では 1 時間降水量の階級を 5〜7 mm, 7〜11 mm というような 範囲により分類したのではなく, $5 \mathrm{~mm}$ 以上, $7 \mathrm{~mm}$ 以 上‥というように下限値により分類しているため，1 時 間降水量が多いほど年最大風速は低く (表一2参照), また, 1 時間降水量が多いほど同じ再現期間に対する風 速は低くなければならない（すなわち，1 時間降水量が $5 \mathrm{~mm}$ 以上, $7 \mathrm{~mm}$ 以上…の各々に対する二重指数確率 紙上の直線が，互いに交差することはない)。これらの 関係から, 本報では既報 ${ }^{51-7)}$ と同様, 降雨時の年最大風 速 $(V)$ は 1 時間降水量 $(H)$ に反比例すると仮定し, 降雨 時の年最大風速 $(V)$ を規準極值変量 $(y)$ と 1 時間降水量 (H)の線形結合により表した（ 7 ）式をモデルとして用 い, 重回帰分析により定数 $C_{0}, C_{1}, C_{2}$ の値を求めた。

$$
V=C_{0}+C_{1} y+C_{2} H
$$

$$
\text { ただし, } \begin{aligned}
H: 1 \text { 時間降水量 } \\
C_{0}, C_{1}, C_{2} \text { : 定数 }
\end{aligned}
$$

すなわち, 1 時間降水量の階級 $\left(H_{i}\right)$ ごとの年最大風速の 観測值 $\left(V_{t}\right)$ とその非超過確率 $\left(F_{i}\right)$ のデー夕を用い（表 -2 参照),

$$
\begin{aligned}
& \tilde{V}_{i}=C_{0}+C_{1} y_{i}+C_{i} H_{i} \\
& y_{i}=-1 n\left(-1 n F_{i}\right) \cdots
\end{aligned}
$$

に代入して得られる推定值 $\tilde{V}_{i}$ と観測値 $V_{i}$ の差の平方 和

$$
S e=\sum\left(\tilde{V}_{i}-V_{i}\right)^{2}
$$

を最小にする $C_{0}, C_{1}, C_{2}$ の值を求めた。

なお, 降雨時の年最大風速 $(V)$ と 1 時間降水量の関係 を反比例と仮定したことに関しては，次節に述べる解析 結果において重相関係数が高いことから，今回の解析に 関してはほぼ妥当と考えている。

\section{3. 解析結果}

図一-2 図一6に, 降雨時の年最大風速の分布の例を 示す。また同図中には，重回帰分析による回帰推定値を 直線により示す。図の横軸は規準極值変量 $y$, 非超過確 率 $F(V)$ および再現期間 $T$ を表し, 縦軸は年最大風速 を表す。なお本報では，観測值の統計期間が 13 年間あ るいは 20 年間と極值統計を行う上では必ずしも十分で はない。また年最大風速は, 近年低減傾向にあることが

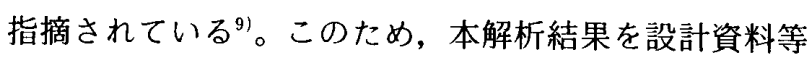
として用いるには統計期間に関する補正が必要と考え,
極值データの個数および年最大風速の低減傾向による再 現期待値の相違に関し, 既往の研究結果 ${ }^{9)}((11),(12)$ 式）を用い，検討を行った。

$$
\begin{aligned}
& V n^{*}=\delta n \cdot V n \\
& \delta n=-0.2551 n(n)+1.85 \\
& \text { ただし, } n: \text { デー夕個数 } \\
& \delta n: \text { 補正係数 } \\
& V n^{*}: 1929 \text { 年から } 1977 \text { 年までの } 49 \text { 年間の } \\
& \text { データにより推定される再現期待值 }
\end{aligned}
$$

その結果得られる補正係数の值は, 統計期間が 13 年間 の場合には1.2(12 年間の場合にも 1.2), 統計期間が 20 年間の場合には 1.1 である。図一2 -図一6に, 上述 の回帰推定値にこれらの補正係数を乗じた結果を破線に より示す。

また表一 3 には, 全国の 49 地点における回帰定数 $C_{0}, C_{1}, C_{2}$ および重相関係数の值, および 1 時間降水 量の階級ごとの風速の 20 年, 50 年, 100 年再現期待値(回 帰推定値に上述の補正係数を乗じた値) を示す。いずれ の都市においても重相関係数はおおむお 0.8 以上であ り，高い精度で回䚻されているといえる。

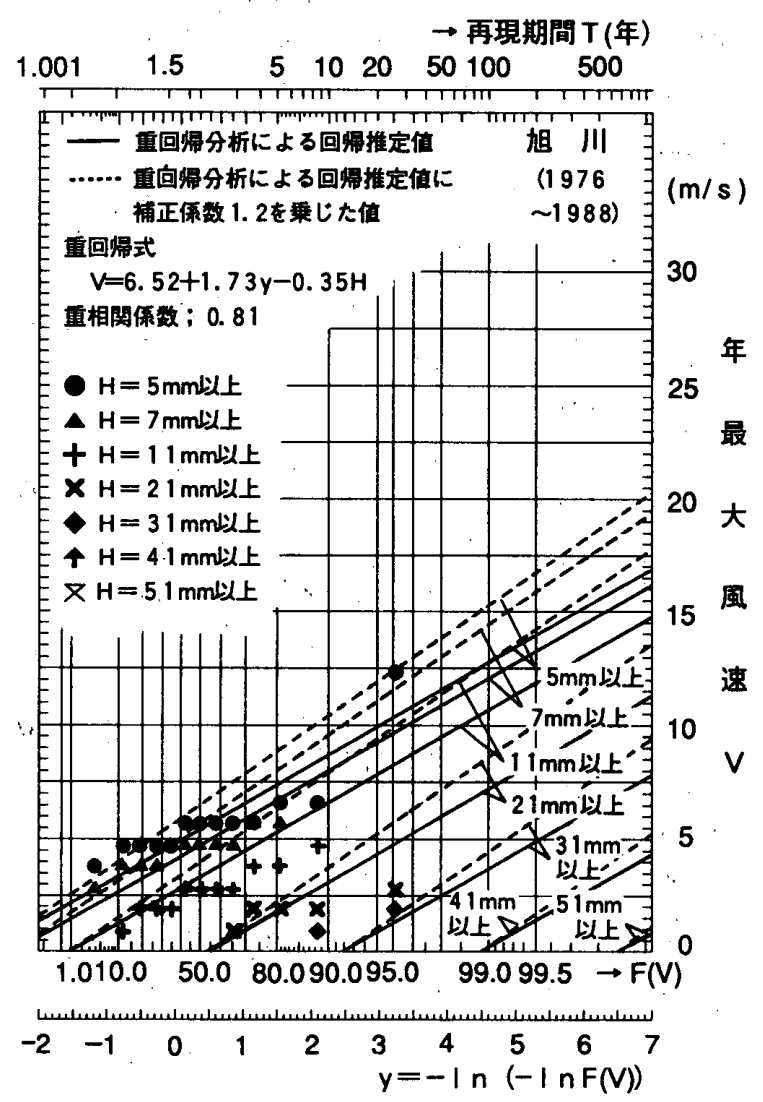

図一2 風と雨が同時に生じる場合の年最大風速の分布 (旭川, 1976 1988) 
$\rightarrow$ 再現期間 T (年)

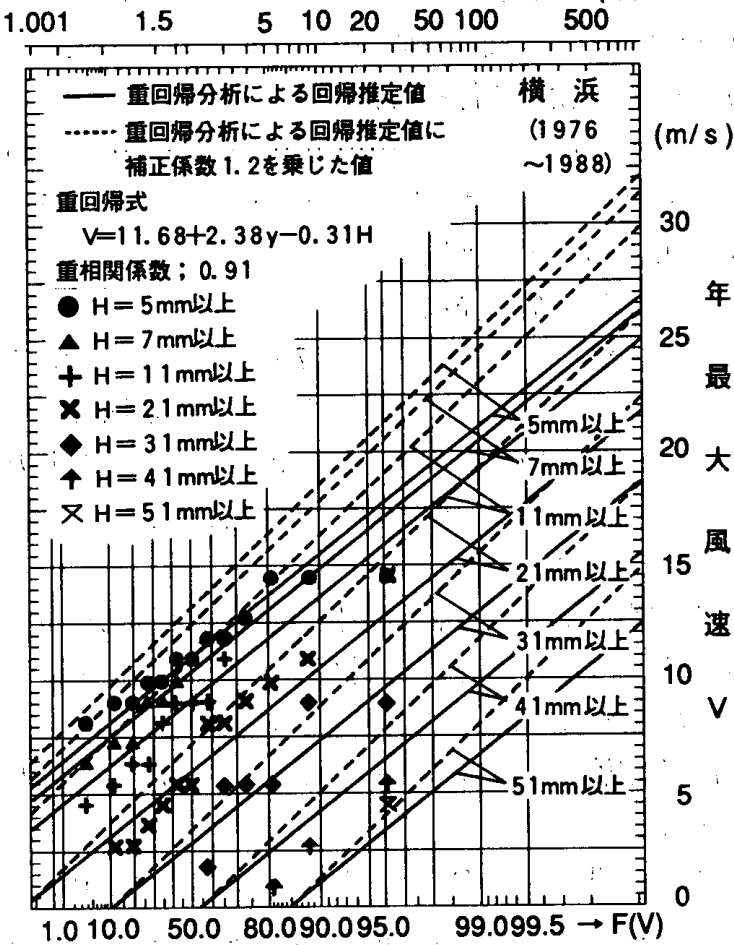

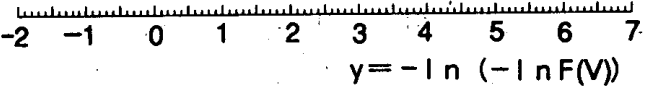

图一3 風之雨が同時に生じる場合の年最大風速の分布 (横浜, 1976 1988)

$\rightarrow$ 再現期間 $\mathrm{T}$ (年)

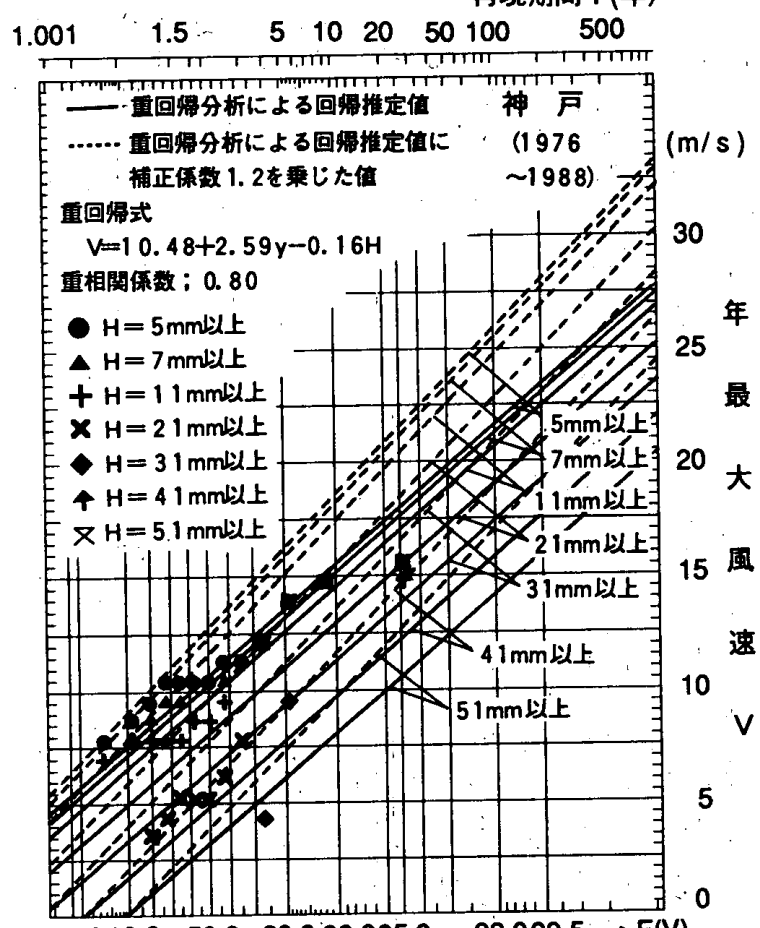

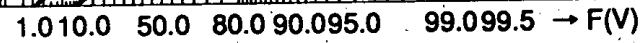

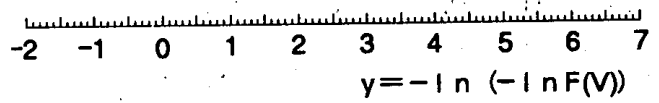

図一4 風と雨が同時に生じる場合の年最大風速の分布 (神戸, 1976 1988) $\rightarrow$ 再現期間 $\mathrm{T}$ (年)

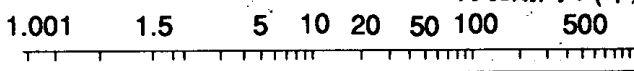

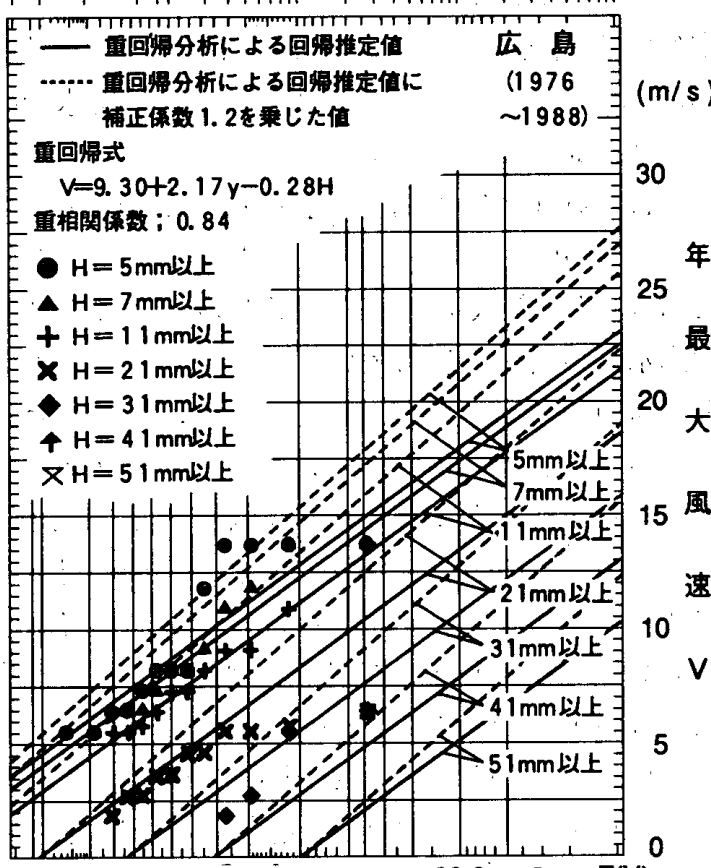

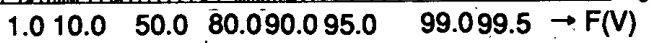

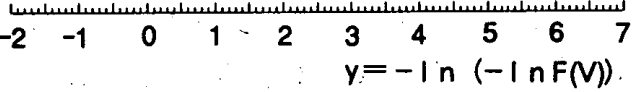

図-5 風と雨が同時に生じる場合の年最大風速の分布 (広島，1976 1988)

$\rightarrow$ 再現期間 T (年)
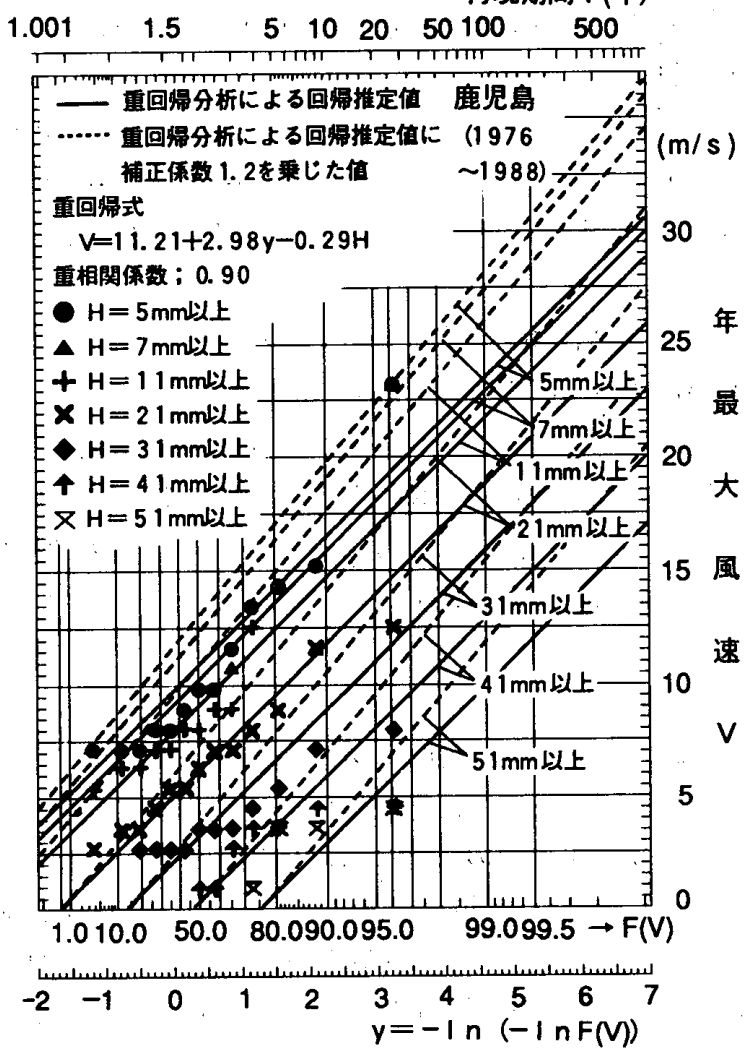

図一6. 風亡雨が同時に生じる場合の年最大風速の分布 （鹿児島, 1976 1988) 
表一3 各地点における解析結果および降雨時の風速の再現期待値

\begin{tabular}{|c|c|c|c|c|}
\hline \multirow{2}{*}{$\begin{array}{l}\text { 地 点 } \\
\text { (( )内は、 } \\
\text { 重相関 } \\
\text { 係数) }\end{array}$} & \multirow{2}{*}{$\begin{array}{l}\text { 回䚻定数 } \\
\text { (上段: C } 0 \\
\text { 中段; C 1 } \\
\text { 下段；C2) }\end{array}$} & \multicolumn{3}{|c|}{$\begin{array}{c}\text { 風速の再現期待值 (単位; } \mathrm{m} / \mathrm{s} \text { ) } \\
\text { (再現期間は、上段:20年, } \\
\text { 中段; } 50 \text { 年.下段;100年) }\end{array}$} \\
\hline & & $H \geqq 5$ & $H \geqq \begin{array}{lll}1 & 1\end{array}$ & $H \geqq 3 \quad 1$ \\
\hline $\begin{array}{l}\text { 䞟 川 } \\
(0.81) \\
\end{array}$ & $\begin{array}{r}6.52 \\
1.73 \\
-0.35 \\
\end{array}$ & $\begin{array}{llll}1 & 1 & 9 \\
1 & 3 & 8 \\
1 & 5 . & 8 \\
\end{array}$ & $\begin{array}{rrr}9 & 9.4 \\
1 & 1.3 \\
12 . & 8 \\
\end{array}$ & $\begin{array}{ll}1.0 \\
3.0 \\
4 . & 4 \\
\end{array}$ \\
\hline $\begin{array}{c}\text { 札 }{ }^{\text {幌 }} \\
(0.96)\end{array}$ & $\begin{array}{r}8.68 \\
1.87 \\
-0.41 \\
\end{array}$ & $\begin{array}{lll}1 & 3 . & 2 \\
1 & 5 & 0 \\
1 & 6 . & 6 \\
\end{array}$ & $\begin{array}{llll}1 & 0 & 5 \\
1 & 2 & . & 1 \\
1 & 3 & 9 \\
\end{array}$ & $\begin{array}{ll}1.7 \\
3 \cdot 7 \\
5 . & 0 \\
\end{array}$ \\
\hline $\begin{array}{l}\text { 画 館 } \\
(0.89)\end{array}$ & $\begin{array}{r}10.39 \\
-0.438 \\
\end{array}$ & $\begin{array}{lll}1 & 5.9 \\
1 & 7.8 \\
1 & 9.2 \\
\end{array}$ & $\begin{array}{lll}1 & 2.8 \\
1 & 4.7 \\
1 & 6 . & 1 \\
\end{array}$ & $\begin{array}{ll}2.6 \\
4.5 \\
5 . & 9 \\
\end{array}$ \\
\hline $\begin{array}{c}\text { 青 森 } \\
(0.087)\end{array}$ & $\begin{array}{r}8.60 \\
1.67 \\
-0.35 \\
\end{array}$ & $\begin{array}{lll}1 & 4 . & 1 \\
1 & 6 . & 0 \\
1 & 7 . & 4 \\
\end{array}$ & 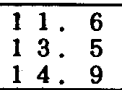 & $\begin{array}{ll}3 \cdot 1 \\
5 \cdot 0 \\
6 . & 4\end{array}$ \\
\hline $\begin{array}{l}\text { 秋 } \\
(0.77) \\
\end{array}$ & $\begin{array}{r}9.15 \\
1.97 \\
-0.27 \\
\end{array}$ & $\begin{array}{llll}1 & 6 & 4 \\
1 & 8.6 \\
2 & 0 . & 2 \\
\end{array}$ & $\begin{array}{lll}1 & 4.4 & 4 \\
1 & 6 . & 7 \\
1 & 8 . & 3 \\
\end{array}$ & $\begin{array}{rrr}8 . & 0 \\
1 & 0 & 2 \\
1 & 1 . & 8 \\
\end{array}$ \\
\hline $\begin{array}{r}\text { 盛 岡 } \\
(0.82) \\
\end{array}$ & $\begin{array}{r}7.59 \\
1.25 \\
-0.20 \\
\end{array}$ & $\begin{array}{lll}1 & 2 . & 4 \\
1 & 3 & 8 \\
1 & 4 . & 8 \\
\end{array}$ & $\begin{array}{lll}1 & 1 & 0 \\
1 & 2 & 0 \\
1 & 3 . & 4 \\
\end{array}$ & $\begin{array}{ll}6 \cdot 3 \\
7 \cdot 7 \\
8 \cdot 7 \\
\end{array}$ \\
\hline $\begin{array}{l}\text { 仙 台 } \\
(0.97) \\
\end{array}$ & $\begin{array}{r}7.77 \\
2.35 \\
-0.24 \\
\end{array}$ & $\begin{array}{lll}1 & 4.7 \\
1 & 7.7 \\
1 & 8.9 \\
\end{array}$ & $\begin{array}{lll}1 & 3 . & 2 \\
1 & 5 . & 6 \\
1 & 7 . & 4 \\
\end{array}$ & $\begin{array}{lll} & 7 . & 8 \\
1 & 0.5 \\
1 & 1 . & 9 \\
\end{array}$ \\
\hline $\begin{array}{c}\text { 山 形 } \\
(0.85)\end{array}$ & $\begin{array}{r}4.85 \\
1.49 \\
-0.16 \\
\end{array}$ & $\begin{array}{lll}1 & 0 & 2 \\
1 & 1 & 9 \\
1 & 3 & 9 \\
\end{array}$ & $\begin{array}{rrr}9 & 1 \\
1 & 0 . & 7 \\
1 & 2 & 0 \\
\end{array}$ & $\begin{array}{ll}5 . & 2 \\
6 . & 9 \\
8 . & 2 \\
\end{array}$ \\
\hline $\begin{aligned}\left.\begin{array}{r}\text { 福 } \\
(0.92\end{array}\right) \\
\end{aligned}$ & $\begin{array}{r}5.86 \\
1.23 \\
-0.15 \\
\end{array}$ & $\begin{array}{llll}1 & 0.5 & 5 \\
1 & 1.9 & 9 \\
1 & 2 . & 9 \\
\end{array}$ & 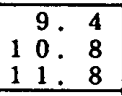 & $\begin{array}{l}5 \cdot 7 \\
7 \cdot 1 \\
8 \cdot 1 \\
\end{array}$ \\
\hline 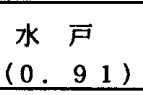 & $\begin{array}{r}10.06 \\
2.17 \\
-0.23 \\
\end{array}$ & \begin{tabular}{l|lll}
1 & 8. & 4 \\
2 & 0. & 8 \\
2 & 2 & 7 \\
\end{tabular} & $\begin{array}{llll}1 & 6 . & 8 \\
1 & 9 & 2 \\
2 & 1 . & 0 \\
\end{array}$ & $\begin{array}{lll}1 & 1.5 \\
1 & 3.6 \\
1 & 5.5 & 4 \\
\end{array}$ \\
\hline $\begin{array}{l}\text { 宇都宮 } \\
(0.87)\end{array}$ & $\begin{array}{r}7.89 \\
1.71 \\
-0.15 \\
\end{array}$ & $\begin{array}{lll}1 & 4.7 \\
1 & 6.6 \\
1 & 8.0 \\
\end{array}$ & $\begin{array}{lll}1 & 3 & 6 \\
1 & 5 & 6 \\
1 & 7 & 6 \\
\end{array}$ & $\begin{array}{lll}1 & 0 & 2 \\
1 & 2 & \vdots \\
1 & 3 & 1 \\
\end{array}$ \\
\hline $\begin{array}{l}\text { 前 橋 } \\
(0.91) \\
\end{array}$ & $\begin{array}{r}7.71 \\
2.13 \\
-0.22 \\
\end{array}$ & $\begin{array}{lll}1 & 5.6 \\
1 & 7.9 \\
1 & 9.7 \\
\end{array}$ & $\begin{array}{lll}1 & 4.0 \\
1 & 6 . & 4 \\
1 & 8 . & 2 \\
\end{array}$ & $\begin{array}{rrr} & 8 . & 8 \\
1 & 1 . & 2 \\
1 & 3 . & 0 \\
\end{array}$ \\
\hline $\begin{array}{r}\text { 熊 谷 } \\
\left(\begin{array}{lll}0 . & 9 & 3\end{array}\right) \\
\end{array}$ & $\begin{array}{r}7.98 \\
1.86 \\
-0.17 \\
\end{array}$ & $\begin{array}{lll}1 & 5.2 & 2 \\
1 & 7.2 \\
1 & 8.8 \\
\end{array}$ & $\begin{array}{lll}1 & 3.9 \\
1 & 6.9 \\
1 & 7 . & 5 \\
\end{array}$ & $\begin{array}{r}9.7 \\
11 \\
13.8 \\
13.4 \\
\end{array}$ \\
\hline $\begin{array}{l}\text { 果 } \\
(0.97) \\
\end{array}$ & $\begin{array}{r}8.87 \\
2.35 \\
-0.21 \\
\end{array}$ & $\begin{array}{llll}1 & 6 . & 1 \\
1 & 8 . & 5 \\
2 & 0 . & 4 \\
\end{array}$ & $\begin{array}{lll}1 & 4.5 \\
1 & 7.8 \\
1 & 9 . & 0 \\
\end{array}$ & $\begin{array}{rr}9.5 \\
12.5 \\
14.2 \\
\end{array}$ \\
\hline $\begin{array}{c}\text { 千 賲 } \\
(0.86) \\
\end{array}$ & $\begin{array}{r}13.29 \\
3.00 \\
-0.45 \\
\end{array}$ & \begin{tabular}{|lll} 
& 3 & 9 \\
2 & 7 & 9 \\
2 & 9 & 8 \\
\end{tabular} & \begin{tabular}{|lll}
2 & 0.7 \\
2 & 4 & 7 \\
2 & 6 & 0 \\
2 & 6 & 5 \\
\end{tabular} & $\begin{array}{r}9.8 \\
13.8 \\
15.6 \\
\end{array}$ \\
\hline $\begin{array}{l}\text { 横 } \\
(0.91) \\
\end{array}$ & $\begin{array}{r}11.68 \\
2.38 \\
-0.31 \\
\end{array}$ & $\begin{array}{llll}2 & 0 & 6 \\
2 & 3 & 3 \\
2 & 5 & 3 \\
\end{array}$ & \begin{tabular}{|lll}
1 & 8. & 4 \\
2 & 1 & 1 \\
2 & 3 & 0 \\
2 & 3 & 0 \\
\end{tabular} & $\begin{array}{lll}1 & 0.9 & 9 \\
1 & 3 & 5 \\
1 & 5 . & 5 \\
\end{array}$ \\
\hline $\begin{array}{c}\text { 長 野 } \\
(0.92) \\
\end{array}$ & $\begin{array}{r}7.66 \\
1.76 \\
-0.23 \\
\end{array}$ & $\begin{array}{llll}1 & 4 . & 1 \\
1 & 6 . & 0 \\
1 & 7 . & 5 \\
\end{array}$ & $\begin{array}{lll}1 & 2 . & 4 \\
1 & 4 & 4 \\
1 & 5 & 9 \\
\end{array}$ & $\begin{array}{r}6.9 \\
8.9 \\
10.3 \\
\end{array}$ \\
\hline $\begin{array}{c}\text { 甲 府 } \\
(0.84) \\
\end{array}$ & $\begin{array}{r}6.56 \\
1.70 \\
-0.19 \\
\end{array}$ & $\begin{array}{lll}1 & 2.8 \\
1 & 4.7 \\
1 & 6 . & 1 \\
\end{array}$ & \begin{tabular}{|lll}
1 & 1 & 5 \\
1 & 3 & 4 \\
1 & 4 & 8 \\
\end{tabular} & $\begin{array}{r}7.0 \\
8.9 \\
10.3 \\
\end{array}$ \\
\hline 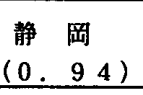 & $\begin{array}{r}9.71 \\
2.14 \\
-0.21 \\
\end{array}$ & $\begin{array}{llll}1 & 8 . & 1 \\
2 & 0 . & 4 \\
2 & 2 . & 2 \\
\end{array}$ & $\begin{array}{llll}1 & 6 . & 6 \\
1 & 9 . & 0 \\
2 & 0 . & 7 \\
\end{array}$ & $\begin{array}{lll}1 & 1.6 & 6 \\
1 & 4 & 0 \\
1 & 5 . & 8 \\
\end{array}$ \\
\hline $\begin{array}{c}\begin{array}{c}\text { 名古屋 } \\
(0.97)\end{array} \\
\end{array}$ & $\begin{array}{r}10.40 \\
3.26 \\
-0.25 \\
\end{array}$ & $\begin{array}{llll}2 & 0 . & 6 \\
2 & 4 . & 0 \\
2 & 6 . & 3 \\
\end{array}$ & $\begin{array}{llll}1 & 9 & 0 \\
2 & 2 & 2 \\
2 & 4 & 2 \\
\end{array}$ & $\begin{array}{lll}1 & 3.6 \\
1 & 6.8 \\
1 & 9 . & 2 \\
\end{array}$ \\
\hline $\begin{array}{l}\text { 岥 阜 } \\
(0.91) \\
\end{array}$ & $\begin{array}{r}7.08 \\
1.96 \\
-0.15 \\
\end{array}$ & $\begin{array}{lll}1 & 4.6 \\
1 & 6 . & 8 \\
1 & 8 . & 4 \\
\end{array}$ & $\begin{array}{lll}1 & 3 & 5 \\
1 & 5 & 7 \\
1 & 7 . & 3 \\
\end{array}$ & $\begin{array}{r}9.8 \\
12.8 \\
13.6 \\
\end{array}$ \\
\hline $\begin{array}{c}\text { 津 } \\
(0.92) \\
\end{array}$ & $\begin{array}{r}12.13 \\
3.30 \\
-0.34 \\
\end{array}$ & $\begin{array}{llll}2 & 4 & 3 & 3 \\
2 & 8 & 0 \\
3 & 0 . & 7 \\
\end{array}$ & $\begin{array}{llll}2 & 1 & 8 \\
2 & 5 & 5 \\
2 & 8 . & 3 \\
\end{array}$ & $\begin{array}{lll}1 & 3 & 6 \\
1 & 7 & 3 \\
2 & 0 & 0 \\
\end{array}$ \\
\hline 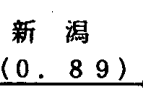 & $\begin{array}{r}12.82 \\
2.56 \\
-0.58 \\
\end{array}$ & $\begin{array}{lll}2 & 1 & 0 \\
2 & 3 & 0 \\
2 & 6 . & 0 \\
\end{array}$ & $\begin{array}{llll}1 & 6 . & 9 \\
1 & 9 & 7 \\
2 & 1 . & 9 \\
\end{array}$ & $\begin{array}{r}2.9 \\
5.8 \\
7.9 \\
\end{array}$ \\
\hline $\begin{array}{l}\text { 富 山 } \\
(0.88) \\
\end{array}$ & $\begin{array}{r}9.62 \\
2.41 \\
-0.26 \\
\end{array}$ & $\begin{array}{lll}1 & 8.6 \\
2 & 1 & 6 \\
2 & 3 & 3 \\
\end{array}$ & $\begin{array}{llll}1 & 6 . & 7 \\
1 & 9 & 4 \\
2 & 1 . & 4 \\
\end{array}$ & $\begin{array}{lll} & 0.4 & 4 \\
1 & 3 & 1 \\
1 & 5 . & 2 \\
\end{array}$ \\
\hline 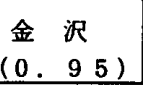 & $\begin{array}{r}855 \\
1.05 \\
-0.25 \\
\end{array}$ & $\begin{array}{lll}1 & 2 & 5 \\
1 & 3 & 5 \\
1 & 4 & 7 \\
\end{array}$ & $\begin{array}{llll}1 & 0 & 8 \\
1 & 2 & 0 \\
1 & 2 & 8 \\
\end{array}$ & $\begin{array}{ll}4.9 \\
6 \cdot 9 \\
7 . & 0 \\
\end{array}$ \\
\hline
\end{tabular}

\begin{tabular}{|c|c|c|c|c|}
\hline \multirow{2}{*}{$\begin{array}{l}\text { 地 点 } \\
(() \text { 内は、 } \\
\text { 重相関 } \\
\text { 係数) }\end{array}$} & \multirow{2}{*}{$\begin{array}{l}\text { 回帰定数 } \\
\text { (上段; C } 0 \\
\text { 中段; C 1 } \\
\text { 下段：C 2) }\end{array}$} & \multicolumn{3}{|c|}{$\begin{array}{c}\text { 風速の再現期待值 (単位: } \mathrm{m} / \mathrm{s} \text { ) } \\
\text { (再現期間は、上段: } 20 \text { 年, } \\
\text { 中段: } 50 \text { 年.下段; } 100 \text { 年) }\end{array}$} \\
\hline & & $H \geqq 5$ & $H \geqq 1 \quad 1$ & $H \geqq 3 \quad 1$ \\
\hline 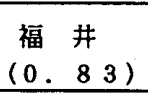 & $\begin{array}{r}8.67 \\
1.92 \\
-0.28 \\
\end{array}$ & $\begin{array}{lll}1 & 5 & 6 \\
1 & 7 & 6 \\
1 & 9 & 9 \\
\end{array}$ & $\begin{array}{lll}1 & 3.5 \\
1 & 5 & 7 \\
1 & 7 . & 3 \\
\end{array}$ & $\begin{array}{r}6.8 \\
8.9 \\
10.5 \\
\end{array}$ \\
\hline $\begin{array}{r}\text { 彦 根 } \\
(0.92) \\
\end{array}$ & $\begin{array}{r}8.60 \\
1.67 \\
-0.24 \\
\end{array}$ & $\begin{array}{lll}1 & 4.8 \\
1 & 6.8 & 7 \\
1 & 8 . & 1 \\
\end{array}$ & $\begin{array}{lll}1 & 3 & 1 \\
1 & 4 & 9 \\
1 & 6 . & 3 \\
\end{array}$ & $\begin{array}{r}7.3 \\
9.3 \\
10.6 \\
\end{array}$ \\
\hline $\begin{array}{c}\text { 京 都 } \\
(0.90)\end{array}$ & $\begin{array}{r}5.65 \\
1.43 \\
-0.14 \\
\end{array}$ & $\begin{array}{lll}1 & 1 . & 0 \\
1 & 2 & 0 \\
1 & 3 . & 8 \\
\end{array}$ & $\begin{array}{llll}1 & 0 & 0 \\
1 & 1 & 0 \\
1 & 2 & 6 \\
\end{array}$ & $\begin{array}{ll}6.6 \\
8.2 \\
9.4 \\
\end{array}$ \\
\hline $\begin{array}{c}\text { 大 } \text { 阪 } \\
(0.98) \\
\end{array}$ & $\begin{array}{r}10.83 \\
3.41 \\
-0.34 \\
\end{array}$ & \begin{tabular}{|lll}
2 & 1 & 1 \\
2 & 4 & 1 \\
2 & 7 & 5 \\
\end{tabular} & $\begin{array}{llll}1 & 8 . & 9 \\
2 & 2 . & 0 \\
2 & 5 . & 0 \\
\end{array}$ & $\begin{array}{lll}1 & 1.5 \\
1 & 5.5 & 6 \\
1 & 7 . & 5 \\
\end{array}$ \\
\hline $\begin{array}{l}\text { 神 } \\
(0.80) \\
\end{array}$ & $\begin{array}{r}10.48 \\
2.59 \\
-0.16 \\
\end{array}$ & $\begin{array}{lll}2 & 0.9 \\
2 & 3 & 8 \\
2 & 5 . & 9 \\
\end{array}$ & $\begin{array}{lll}1 & 9 \cdot 7 \\
2 & 2 & 7 \\
2 & 4 . & 7 \\
\end{array}$ & $\begin{array}{lll}1 & 5.9 \\
1 & 8.7 \\
2 & 0.9 & 9 \\
\end{array}$ \\
\hline $\begin{array}{c}\text { 奈 良 } \\
(0.81) \\
\end{array}$ & $\begin{array}{r}7.11 \\
1.53 \\
-0.22 \\
\end{array}$ & $\begin{array}{lll}1 & 2.7 \\
1 & 4.4 \\
1 & 5.7 & 7 \\
\end{array}$ & $\begin{array}{llll}1 & 1 & 1 \\
1 & 2 & 1 \\
1 & 4 . & 8 \\
\end{array}$ & $\begin{array}{ll}6.0 \\
7.7 \\
9.0 \\
\end{array}$ \\
\hline $\begin{array}{l}\text { 和歌山 } \\
(0.84) \\
\end{array}$ & $\begin{array}{r}11.38 \\
2.45 \\
-0.26 \\
\end{array}$ & $\begin{array}{llll} & 0 & 8 \\
2 & 3 & 8 \\
2 & 5 & 6 \\
2 & 5 & 6 \\
\end{array}$ & $\begin{array}{llll}1 & 8 & 9 \\
2 & 1 & 9 \\
2 & 3 & 7 \\
\end{array}$ & $\begin{array}{lll}1 & 2 & 6 \\
1 & 5 & 3 \\
1 & 7 . & 4 \\
\end{array}$ \\
\hline $\begin{array}{l}\text { 岡 } \\
(0.86) \\
\end{array}$ & $\begin{array}{r}6.92 \\
1.70 \\
-0.24 \\
\end{array}$ & $\begin{array}{lll}1 & 2.9 \\
1 & 4.8 \\
1 & 6.2 & 2 \\
\end{array}$ & $\begin{array}{lll}1 & 1.5 \\
1 & 3.5 & 1 \\
1 & 4.5 & 5 \\
\end{array}$ & $\begin{array}{ll}5.5 \\
7.4 \\
8.8 \\
\end{array}$ \\
\hline 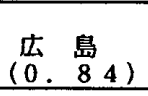 & $\begin{array}{r}9.30 \\
2.17 \\
-0.28 \\
\end{array}$ & $\begin{array}{llll}1 & 7 . & 2 \\
1 & 9 . & 7 \\
2 & 1.5 & 5 \\
\end{array}$ & $\begin{array}{lll}1 & 5.2 \\
1 & 7.2 \\
1 & 9 & 5 \\
\end{array}$ & $\begin{array}{lll} & 8.5 \\
1 & 1 & 5 \\
1 & 2 . & 8 \\
\end{array}$ \\
\hline $\begin{array}{l}\text { 松. I } \\
(0.87) \\
\end{array}$ & $\begin{array}{r}11.65 \\
2.45 \\
-0.37 \\
\end{array}$ & $\begin{array}{llll}2 & 0 . & 5 \\
2 & 3 & 3 \\
2 & 5 . & 3 \\
\end{array}$ & $\begin{array}{llll}1 & 7 & 9 \\
2 & 0 & 9 \\
2 & 2 & 6 \\
\end{array}$ & $\begin{array}{r}9.8 \\
11.8 \\
13.8 \\
\end{array}$ \\
\hline 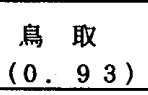 & $\begin{array}{r}9.42 \\
1.76 \\
-0.28 \\
\end{array}$ & $\begin{array}{lll}15.9 \\
15 & 7.9 \\
1 & 9.4 \\
\end{array}$ & $\begin{array}{llll}1 & 3 . & 9 \\
1 & 5 . & 9 \\
1 & 7 . & 4 \\
\end{array}$ & $\begin{array}{r}7.3 \\
9.2 \\
10.7 \\
\end{array}$ \\
\hline 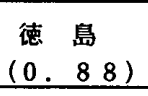 & $\begin{array}{r}10.75 \\
3.89 \\
-0.22 \\
\end{array}$ & $\begin{array}{llll}2 & 5 . & 4 \\
2 & 9 . & 8 \\
3 & 3 . & 0 \\
\end{array}$ & $\begin{array}{llll}2 & 3 . & 8 \\
2 & 8 . & 2 \\
3 & 1 . & 4 \\
\end{array}$ & $\begin{array}{lll}1 & 8.5 \\
2 & 2 . & 9 \\
2 & 6 . & 1 \\
\end{array}$ \\
\hline $\begin{array}{l}\text { 高. 松 } \\
(0.85) \\
\end{array}$ & $\begin{array}{r}7.58 \\
3.14 \\
-0.19 \\
\end{array}$ & $\begin{array}{lll}1 & 9 & 1 \\
2 & 2 & 7 \\
2 & 5 & 7 \\
\end{array}$ & $\begin{array}{llll}1 & 7 . & 8 \\
2 & 1 . & 3 \\
2 & 3 . & 9 \\
\end{array}$ & $\begin{array}{lll}1 & 3 & 2 \\
1 & 6 & 7 \\
1 & 9 . & 3 \\
\end{array}$ \\
\hline $\begin{array}{l}\text { 松 } \\
(0.88) \\
\end{array}$ & $\begin{array}{r}6.58 \\
1.53 \\
-0.23 \\
\end{array}$ & $\begin{array}{lll}1 & 2 & 0 \\
1 & 3 & \\
1 & 5 . & 7 \\
1 & 5 . & 0 \\
\end{array}$ & $\begin{array}{llll}1 & 0 . & 4 \\
1 & 2 & . & 1 \\
1 & 3 . & 3 \\
\end{array}$ & $\begin{array}{l}4.9 \\
6.6 \\
7.9 \\
\end{array}$ \\
\hline 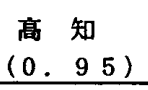 & $\begin{array}{r}8.06 \\
2.05 \\
-0.14 \\
\end{array}$ & $\begin{array}{lll}1 & 6 & 1 \\
1 & 8 & 1 \\
2 & 0 . & 4 \\
\end{array}$ & $\begin{array}{lll}1 & 5 & 1 \\
1 & 7.4 \\
1 & 9 . & 1 \\
\end{array}$ & $\begin{array}{lll}1 & 1 & 7 \\
1 & 3 & 9 \\
1 & 5 & 9 \\
\end{array}$ \\
\hline $\begin{array}{c}\text { 山 } \square \\
(0.87) \\
\end{array}$ & $\begin{array}{r}11.82 \\
2.83 \\
-0.39 \\
\end{array}$ & $\begin{array}{lll}2 & 1.9 \\
2 & 5 & 9 \\
2 & 7 . & 5 \\
\end{array}$ & $\begin{array}{llll}1 & 9 . & 2 \\
2 & 2 & 3 \\
2 & 4 & 7 \\
\end{array}$ & $\begin{array}{r}9.9 \\
13.9 \\
15.4 \\
\end{array}$ \\
\hline 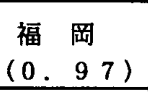 & $\begin{array}{r}12.12 \\
2.86 \\
-0.34 \\
\end{array}$ & $\begin{array}{llll}2 & 0 . & 7 \\
2 & 4 & 0 \\
2 & 6 . & 2 \\
\end{array}$ & $\begin{array}{llll}1 & 8 & 5 \\
2 & 1 & 0 \\
2 & 3 & 8 \\
\end{array}$ & $\begin{array}{llll}1 & 1 . & 0 \\
1 & 3 & 0 \\
1 & 6 . & 2 \\
\end{array}$ \\
\hline $\begin{array}{l}\text { 大 } \text { 分 } \\
10.88 \\
\end{array}$ & $\begin{array}{r}8.04 \\
2.23 \\
-0.18 \\
\end{array}$ & $\begin{array}{llll}1 & 6 . & 5 \\
1 & 9 & 0 \\
2 & 0 . & 9 \\
\end{array}$ & $\begin{array}{lll}1 & 5 . & 2 \\
1 & 7 & 0 \\
1 & 9 . & 6 \\
\end{array}$ & $\begin{array}{lll}1 & 0 . & 8 \\
1 & 3 & 3 \\
1 & 5 . & 2 \\
\end{array}$ \\
\hline 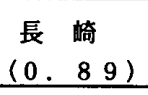 & $\begin{array}{r}9.90 \\
1.76 \\
-0.16 \\
\end{array}$ & $\begin{array}{lll}1 & 7 . & 2 \\
1 & 9 . & 2 \\
2 & 0 . & 6 \\
\end{array}$ & $\begin{array}{lll}1 & 6 . & 0 \\
1 & 8 . & 0 \\
1 & 9 . & 5 \\
\end{array}$ & $\begin{array}{llll}1 & 2 . & 2 \\
1 & 4 . & 2 \\
1 & 5 . & 6 \\
\end{array}$ \\
\hline $\begin{array}{c}\text { 佐 資 } \\
(0.90 \\
\end{array}$ & $\begin{array}{r}10.82 \\
3.45 \\
-0.25 \\
\end{array}$ & $\begin{array}{lll}2 & 3 . & 8 \\
2 & 7 & 6 \\
3 & 0 . & 5 \\
\end{array}$ & $\begin{array}{lll}2 & 2 & 0 \\
2 & 5 & 0 \\
2 & 8 . & 7 \\
\end{array}$ & $\begin{array}{lll}1 & 6 . & 1 \\
1 & 9 . & 9 \\
2 & 2 & 8 \\
\end{array}$ \\
\hline $\begin{array}{l}\text { 熊本 } \\
(0.066 \\
\end{array}$ & $\begin{array}{r}8.75 \\
1.27 \\
-0.17 \\
\end{array}$ & $\begin{array}{llll}1 & 4 . & 0 \\
1 & 5 & 4 \\
1 & 6 . & 5 \\
\end{array}$ & $\begin{array}{lll}1 & 2 . & 7 \\
1 & 4 . & 2 \\
1 & 5 . & 2 \\
\end{array}$ & $\begin{array}{lll} & 8.6 \\
1 & 0 . & 0 \\
1 & 1 . & 1 \\
\end{array}$ \\
\hline 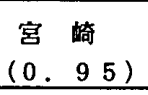 & $\begin{array}{r}12.19 \\
2.37 \\
-0.25 \\
\end{array}$ & $\begin{array}{llll}2 & 1 . & 5 \\
2 & 4 & 2 \\
2 & 6 . & 2 \\
\end{array}$ & $\begin{array}{llll}1 & 9 & 7 \\
2 & 2 . & 4 \\
2 & 4 . & 4 \\
\end{array}$ & $\begin{array}{llll}1 & 3 . & 6 \\
1 & 6 . & 2 \\
1 & 8 . & 2 \\
\end{array}$ \\
\hline $\begin{array}{c}\left.\begin{array}{c}\text { 鹿児島 } \\
(0.90\end{array}\right) \\
\end{array}$ & $\begin{array}{r}11.21 \\
2.98 \\
-0.29 \\
\end{array}$ & \begin{tabular}{lll|}
2 & 2 & 3 \\
2 & 5 & 6 \\
2 & 8 & 1 \\
\end{tabular} & $\begin{array}{llll}2 & 0 . & 2 \\
2 & 3 & 5 \\
2 & 6 & 5 \\
\end{array}$ & $\begin{array}{lll}1 & 3 . & 1 \\
1 & 6 . & 5 \\
1 & 9 & 0 \\
\end{array}$ \\
\hline 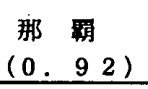 & $\begin{array}{r}20.25 \\
3.00 \\
-0.34 \\
\end{array}$ & $\begin{array}{lll}3 & 2 & 9 \\
3 & 6 . & 3 \\
3 & 8 . & 8 \\
\end{array}$ & $\begin{array}{llll}3 & 0 & 4 \\
3 & 3 & 8 \\
3 & 6 . & 3 \\
\end{array}$ & $\begin{array}{llll}2 & 2 & 2 \\
2 & 5 & 5 \\
2 & 8 & 5 \\
\end{array}$ \\
\hline
\end{tabular}

(注 1 ) $\mathrm{H}: 1$ 時間降水量

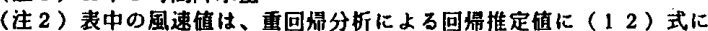
よる㭪正保数を烡した值（地上１０ｍにたける值）を示す。 


\section{4. 風速の鉛直分布に関する換算方法および降雨時の風 速の算定例}

本報では，各気象官署の風速を（1）式により地上： $10 \mathrm{~m}$ におりる風速に換算し，解析に用いている。この ため解析結果から得られる風速の再現期待值は，地上 $10 \mathrm{~m}$ における值である。したがって任意高さ $h$ におけ る風速は，地上 $10 \mathrm{~m}$ における風速を（13）式を用いて 気象官署の観測高さでの風速値に戻し!"さらにその值を （14）式を用いて高さ $h$ における風速伹に換算し求め られる!

$$
\begin{aligned}
& V_{M}=V_{10} \cdot\left(h_{M} / 10\right)^{1 / i} \ldots \ldots \ldots \ldots . \\
& V_{h}=V_{M} \cdot\left(Z_{G}^{M} / h_{M}^{-}\right)^{\alpha M} \cdot\left(h / Z_{G}^{A}\right)^{\alpha_{A}}
\end{aligned}
$$

ただし; $V_{M}$ : 気象官署の風速観測高さ $\left(h_{M}\right)$ における 10 分間平均風速 $(\mathrm{m} / \mathrm{s})$

$V_{10}$ : 地上 $10 \mathrm{~m}$ における 10 分間平均風速 $(\mathrm{m} / \mathrm{s})$

$V_{h}:$ 建設地点の地上 $h(\mathrm{~m})$ における 10 分間 平均風速 $(\mathrm{m} / \mathrm{s})$

$h_{M}$ : 気象官署の風速観測高さ (単位; $\mathrm{m}$, 表 -1 参照)。

$h:$ 地表面からの高さ $(\mathrm{m})$ 。ただし，建設 地点の地表面粗度区分に応じて定まる定 数 $Z_{b}$ (表一 4 参照) に対し, $h \leqq Z_{b}$ の 場合には $h=Z_{b}$ とする。

$Z_{G}^{M}, \alpha_{M}$ : 気象官署地点 $M$ の地表面粗度区分に応 じて定まる定数 $Z_{G}, \alpha$ の値（表一 4 参照）

$Z_{G}^{A}, \alpha_{A}:$ 建設地点 $A$ の地表面粗度区分に応じて 定まる定数 $Z_{G}, \alpha$ の值（表一 4 参照）

以下に算定例として，旭川において 1 時間降水量が $15 \mathrm{~mm}$ 以上の場合の風速の 20 年再現期待值（地上 $50 \mathrm{~m}$ における値) を求める手順を示す。

(1) 表一 3 より, 旭川における定数 $C_{0}, C_{1}, C_{2}$ の值を 求める。

$$
C_{0}=6.52, C_{1}=1.73, C_{2}=-0.35
$$

(2) (4)，(5) 式より，再現期間 20 年に対する規準極 値変量 $y$ の值を求める。

$$
\begin{aligned}
& T=20 \text { (年) } \\
& F\left(V_{T}\right)=1-1 / T=0.95 \\
& y=-1 n\left(-1 n F\left(V_{T}\right)\right)=2.97
\end{aligned}
$$

(3)（7) 式に， $C_{0}, C_{1} ， C_{2}$ および $y$ の值を代入し，ま た 11 時間降水量 $H$ を $15(\mathrm{~mm})$ として，風速の 20 年再現期待值を求める。

$$
V=C_{0}+C_{1} y+C_{2} H=6.4(\mathrm{~m} / \mathrm{s})
$$

(4)（12）式による補正係数 1.2 を乗じ，統計期間によ

\begin{tabular}{|c|c|c|}
\hline $\begin{array}{l}\text { 地表面 } \\
\text { 粗度区分 }\end{array}$ & 周辺地域の地表面の状況 & 代表例 \\
\hline $\mathbf{I}$ & 障害物のほとんどない平たん地 & 海岸地带 \\
\hline II & $\begin{array}{l}\text { 農作物程度の障害がある地域お } \\
\text { よび樹木・低層建筑物などが散 } \\
\text { 在している地域 }\end{array}$ & 田園地帯 \\
\hline III & $\begin{array}{l}\text { 樹木・低層建築物などが密集し } \\
\text { ている地域およびれ：高層建築 } \\
\text { 物が散在しててる地域 }\end{array}$ & $\begin{array}{l}\text { 森林地带 } \\
\text { 工場地帯 } \\
\text { 住 宅 地 }\end{array}$ \\
\hline IV & $\begin{array}{l}\text { 中・高層建築物が広範囲に密集 } \\
\text { している地域 }\end{array}$ & $\begin{array}{l}\text { 中・高層 } \\
\text { 市 街 地 }\end{array}$ \\
\hline
\end{tabular}
る再現期待值の相違を補正する。

$$
V^{\prime}=6.4 \times 1.2=7.7(\mathrm{~m} / \mathrm{s})
$$

(5) 気象官署地点および建設地点での粗度区分を而と仮 定し，(13），(14）式により地上 $50 \mathrm{~m}$ における風速
表一4'風速の鉛直分布に関するパラメー夕*

(a) 地表面粗度区分

(b) $Z_{b}, Z_{G}, \alpha$ の値

\begin{tabular}{|c|c|c|c|c|}
\hline $\begin{array}{l}\text { 地表面 } \\
\text { 粗度区分 }\end{array}$ & I & II & III & IV \\
\hline$Z_{\mathrm{b}}$ & 5 & 10 & 15 & 30 \\
\hline$Z_{G}$ & 200 & 250 & 350 & 450 \\
\hline$\alpha$ & 0.11 & 0.15 & 0.2 & 0.3 \\
\hline
\end{tabular}

（*) 日本建築学会「建策物荷重指針・同解説」より

$$
\begin{aligned}
\text { を求める。 } \\
V_{M}=7.7 \times(14.7 / 10)^{1 / 7}=8.1(\mathrm{~m} / \mathrm{s}) \\
V_{h}=8.1 \times(350 / 14.7)^{0.2} \times(50 / 350)^{0.2} \\
\quad=10.3(\mathrm{~m} / \mathrm{s})
\end{aligned}
$$

以上により，1時間降水量が $15 \mathrm{~mm}$ 以上の場合の風速

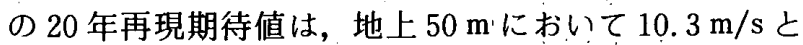
推定される。

\section{5.まとめ}

全国の 49 地点において，風雨の観測資料より降雨時 の年最大風速を抽出し, 風之雨が同時に生じる場合の風 速の再現期待値を極值統計理論により推定した。

本解析結果が、水密設計をばじめとする種々の問題の 検討に資することができれば幸いである。

\section{謝. 辞}

、降水量および風速の観測資料は，地域気象観測資料時 日別ファイル（気象庁提供）を使用致しました。ここに 記して，感謝の意を表します。

\section{参考文献}

1)：日本気象協会：日本各地の年最大風速（1929 1966）, 気 象庁観測技術資料，No. 34，1971.1

2) 中原満雄: 年最大風速の再現期待值, 建築研究資料, No. 26, 建設省建築研究所, - 1981.3

3）中原満雄，田村幸雄，浅見”豊，新堀喜則，吉川祐三： 日本における建築物設計用の基準風速分布四，日本建築 学会論文報告集, No. 336, 1984.2

4）勝甶高司, 寺沢達二, 片山忠久：金属性サッシの気密・ 水密に関する実験的研究，東京大学生産技術研究所報告, 
Vol. 20, No. 2, 1970.8

5）村上周三, 森川泰成, 岩佐義煇, 茅野紀子 : 降雨を伴う 風速の再現期待值, 生産研究, Vol. 34, No. 4, 東京大学 生産技術研究所, 1982.4

6）村上周三, 岩佐義輝, 森川泰成, 茅野紀子 : 降雨を伴う 風速の再現期待值, 日本風工学会誌, No. 27, 1986.3

7) Murakami Shuzo, Iwasa Yoshiteru, Morikawa Yasushige and Chino Noriko: Extreme Wind Speeds for Various Return Periods during Rainfall, Journal of Wind
Engineering and Industrial Aerodynamics, Vol.26, pp. 105 125, 1987

8）岩井重久, 石黒政儀：応用水文統計学, 森北出版, 1970

9）藤野陽三, 伊藤 学, 酒井利夫：年最大風速記録に上る 設計基本風速の算定に関する研究, 土木学会論文報告集, No. $305,1981.1$

(1991 年 6 月 10 日原稿受理, 1992 年 2 月 3 日採用決定) 